\title{
Analysis of the Critical Success Factors of Integrated Financial Management Information Systems in Selected Kenyan Counties
}

\author{
Elyjoy Muthoni Micheni \\ Department of Management Science and Technology, Technical University of Kenya, Nairobi, Kenya
}

\section{Email address:}

elyjoymicheni@gmail.com

\section{To cite this article:}

Elyjoy Muthoni Micheni. Analysis of the Critical Success Factors of Integrated Financial Management Information Systems in Selected Kenyan Counties. Journal of Finance and Accounting. Vol. 5, No. 5, 2017, pp. 185-192. doi: 10.11648/j.jfa.20170505.12

Received: May 3, 2017; Accepted: May 19, 2017; Published: October 23, 2017

\begin{abstract}
This study sets out to analyze the critical success factors of integrated financial management systems in selected county governments in Kenya. The study focused on the following objectives: perceived benefits, top management commitment, change management, human capital development and technological infrastructural development as success factors for IFMIS implementation at county governments. A descriptive survey was adopted targeting 135 county employees who use IFMIS in selected counties. The research sample size consisted of 45 county employees in Kiambu, Bungoma, Machakos, Nairobi and Nakuru counties. The study involved finance departments of two counties with significant financial wastage and 3 counties with good financial records. The sampling technique used was snowballing sampling technique which involved 45 participants. Questionnaires were the main tool for data collection. A pilot study was conducted using 10 IFMIS employees in Mombasa County. It enabled the researcher to improve on reliability of the instrument used and familiarize researcher with data collection process. Data obtained was both quantitative and qualitative. Quantitative data was coded and keyed into an SPSS package for statistical analysis. The study revealed that change management, technological infrastructure, human capital development and top management commitment are all critical success factors in adoption of IFMIS in county governments. The study recommends that for IFMIS implementation to be very effective and efficient in enhancing transparency and accountability within the counties: change management should be handled better; the National treasury and Counties should organize regular skills advancement courses on IFMIS, encourage phased implementation and testing of the financial management software. A political class support is mandatory at county levels to ensure good financial management and hence reduced corruption.
\end{abstract}

Keywords: Integrated Financial Management Information System, Accountability, Kenyan Counties

\section{Introduction}

\subsection{Background of the Study}

With current digital transition and devolution, Integrated Financial Management Information systems (IFMIS) can not only help countries with economic transition gain effective control over their finances, but also enhance transparency and accountability, reducing political discretion and acting as a disincentive to corruption, fraud and misuse [13]. The county governments of Kenya are required by the Public Financial Management (PFM) Act, 2012 to implement IFMIS since 2013 when they became operational. IFMIS refers to the computerization of public financial management processes, from budget preparation and execution to accounting and reporting, with the help of an integrated system for the purpose of financial management [5]. The purpose of using an IFMIS is to improve budget planning and execution by providing timely and accurate data for budget management and decision making. Innovations in ICT offer extensive opportunities for governments to significantly improve the delivery of their services and to interact more openly with their constituents. High-quality experiences with responsive, integrated private sector information systems have led citizens to expect the same kinds of experience from public bodies and agencies [31].

According to [1], the capacity and functionality of an IFMIS can vary from a basic general ledger accounting 
application to a comprehensive system covering budgeting, accounts receivable or payable, cash management, commitment control, debt, assets and liability management, procurement and purchasing, revenue management, human resource management and payroll [31].

While ICT can be used to transform the way in which governments offer their services, it should be acknowledged that a detailed business case for implementing the technology must be undertaken with emphasis on cultural change, greater degree of commitment, organizational structure and business processes [6]. This argument is supported by [15] who assert that many ICT projects initiated by governments fail because they are poorly coordinated and because agencies act too independently.

The IFMIS in Kenya was developed by the Ministry of Finance in 1998 while operation of the system to line ministries started taking place in 2003. The system was Enterprise Resource Planning (ERP) software based on Oracle. Enterprise Resource Planning software is an organization-wide application that integrates its operations through a centralized database which is accessed using a secure network. However, various changes were made to fit the system to the government processes. The Ministry of Finance implemented an Integrated Financial Management Information System (IFMIS) as part of its Public Financial Management (PFM) reforms. This was to ensure that the government managed public resources in the most efficient, effective and transparent manner [7].

According to the IFMIS Strategic plan 2011-2013, the re-engineering process focused on automation of three high-level processes: the budget process, the exchequer process and the payment process. Study by [12] notes that with the devolution of huge amounts of financial resources to the 47 counties, the adoption of IFMIS is now more significant and timely when governments are transforming to digital processes. Providing a solution to financial management at the county level will forestall corruption at the lower tiers of government and ensure that developmental benefits trickle down to the grassroots.

There is broad agreement that a fully functioning IFMIS can improve governance by providing real- time financial information that financial and other managers can use to administer programs effectively, formulate budgets, and manage resources [14]. It is a nerve of accounting, recording and reporting system cutting across the government departments. Despite the mandatory requirement for the county governments to fully implement IFMIS, the Controller of Budget's quarterly reports on the counties' budget implementation review have consistently highlighted the failure of these counties to fully implement IFMIS in their operations, failure to adopt IFMIS limits transparency in financial management and standard financial reporting as highlighted in article 226 of the constitution of Kenya [23]. Study by [3] revealed that staff resistance, top management commitment, system complexity and staff capacity are some of the factors that impede affective implementation IFMIS in county as well as National government. Implementation successes comes about when IFMIS in the Government Ministries focus on user involvement in the implementation process, clear goal setting, top level management support, appropriate infrastructure and support. Since the county governments started using the IFMIS, no effort has been made so far to collect feedback on the benefits and challenges of using the system, or advance the skills of those using the system. It is against this background therefore, that this research study sought to analyze the critical success factors of IFMIS an innovation for financial management at the counties and national government

\subsection{Research Objective}

(1) To establish the influence of Change Management on adoption of Integrated Financial Management Information Systems in Selected Kenyan Counties

(2) To determine the influence of Technological Infrastructure on adoption of Integrated Financial Management Information Systems in Selected Kenyan Counties

(3) To investigate the influence of Human Capital Development on adoption of Integrated Financial Management Information Systems in Selected Kenyan Counties

(4) To determine the influence of Top Management Commitment on adoption of Integrated Financial Management Information Systems in Selected Kenyan Counties

\subsection{Conceptual Framework}

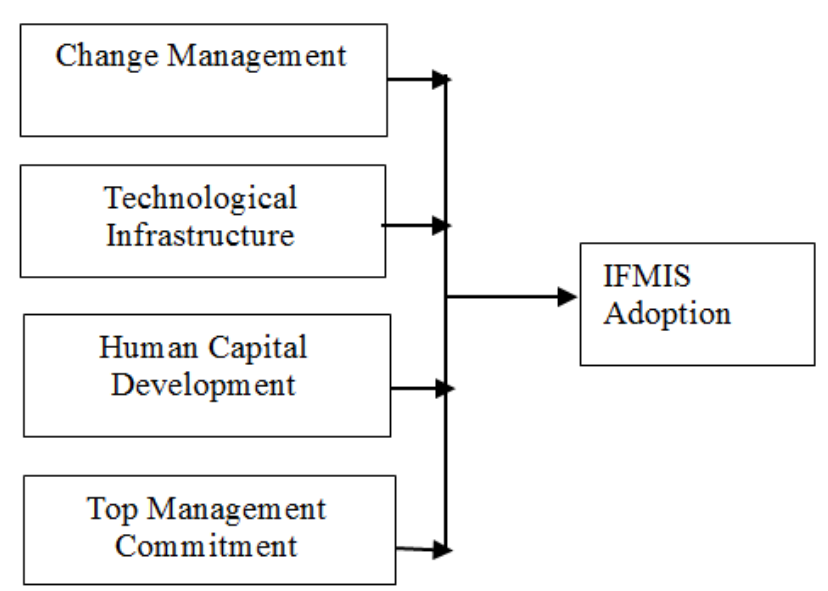

Figure 1. Conceptual Framework.

\section{Literature Review}

\subsection{IFMIS Implementation in Kenya}

The constitution of Kenya, Cap VII Sections 99-103 gives the National Treasury the mandate for proper budgetary and expenditure management of government financial resources. The Ministry's main function concerns the formulation of financial and economic policies that will create an enabling environment for all sectors of the economy to function effectively and efficiently [4]. The system also provides 
real-time financial information that end users can use to formulate budgets, manage resources and oversee projects and programs effectively. According to the [31], sound IFMIS systems coupled with the adoption of centralized treasury operations help developing country governments gain effective control over their finances, and enhance transparency and accountability, reduce political discretion and act as a deterrent to corruption and fraud.

The success of a project implementation is characterized by many factors. "A project is generally considered to be successfully implemented if it: comes in on-schedule (time criterion), comes in on-budget (monetary criterion), achieves basically all goals originally set for it (effectiveness criterion) and it is accepted and used by the clients for whom the project is intended (client satisfaction criterion)" [21]. Alternatively, implementation is assumed to be a success if it achieves a large fraction of its potential benefits for example personnel reductions or a decrease in the cost of information technology. Another description would be that the system accomplishes the level of Return on Investment identified in the project approval thus an ERP implementation should be evaluated based on cost of ownership against quantifiable benefits, taking into account the time [22].

\subsection{Critical Success Factors of IFMIS}

Success factors as those inputs to the management system that lead directly or indirectly to the success of the project or business. IT projects are well known for having high failure rates [29]. It is estimated that about one-third of all IT projects either fail or are abandoned, and around 40 per cent of application development projects are cancelled before completion [29]. According to [30], the process of identifying CSFs helps to ensure that those factors receive the necessary attention.

The Project Management Institute (PMI) defines projects as a means of achieving organizational goals and objectives, often in the context of a strategic plan. Study by [31] notes that, it is important to set out key goals and objectives that need to be achieved in order to give purpose to the vision and mission. In his study, [31] further notes that specific strategic actions then need to be developed against these key goals and objectives and that these actions should be measurable, achievable and have resources and timeframes allocated.

Clear goals and objectives are the third most critical success factor in a study of IT system implementations [21]. Initial phase of any project should begin with a conceptualization of the goals and possible ways to accomplish these goals. Report by [31] found that clearly communicated goals helped companies achieve continuous improvement in system implementations.

Study by [28] found that one of the biggest problems IFMIS systems project leaders face come not from the implementation itself, but from expectations of board members, senior staff, and other key stakeholders. It is thus important to set the goals of the project before even seeking top management support. Report by [24] state that the goals should be realistic in terms of required quality, time and money.

Study by [27] found that a lack of project team expertise is often associated with software development risk. In a survey by [10], it was found that having competent members in the project team is the most important success factor for IT system implementations. Both business and technical knowledge are essential for IS success. Report by [27] identified that knowledge; skills, abilities, and experience in both technical and business aspects are all critical factors in determining a project's success or failure. Analysis by [24] noted that attention should be paid to the composition of the project team which should contain both business and well trained technical team members.

Implementing any system in the organization brings about changes in processes, roles policies and functions. With these changes come resistance from some of those affected. Report by [31] asserts that resistance to change may come from various stakeholders in the organization such as individuals with vested interests who benefited from previous methods, civil servants who see it as a threat to their jobs and people who resist change for the fear of the unknown. Change management is therefore the process of creating, maintaining and systematically evaluating changes that occur in the organization [21]. This can be done through clear communication, education, training and other methods that emphasize on the need and benefits of the change. This can be done through various channels such as the media, workshops, seminars or conferences.

An IFMIS generally implies fundamental changes in operating procedures and should be preceded by a detailed functional analysis of processes, procedures, user profiles and requirements that the system will support [1]. Key high-level government goals will only be achieved if the IFMIS solution supports a wide range of business processes that transcend functional, business, organizational and geographic boundaries. IFMIS design should, therefore, be preceded by detailed functional analysis that underpins current functional processes, procedures, user profiles and requirements that the new system will support [3].

The introduction of an IFMIS can be regarded as an organizational reform which deeply affects work processes and institutional arrangements governing the management of public finance. Challenges and obstacles can have a devastating effect on the success of the implementation and management of the process and should not be underestimated [31]; [25].

As argued by [26], one of the key challenges in implementing of an IFMIS in developing countries is the low capacity for system implementation at sub-national level for example provincial and regional governments. This was experienced in an IFMIS implementation in South Africa where a total of nine provinces were involved. [31] argue that the human resource development issue within government needs prioritization, the education system needs to be aligned with the information and communication technologies (ICT) demands of the country and scarce ICT skills need to be attracted and retained particularly within government. 
According to [1], the commitment of senior managers is one of the most frequently cited factors deciding the success or failure of an information system. [1], however, argues that the Ethiopian case study has proven that what matters most in the process is mid-level management's commitment to reform, as the changes ultimately have to be implemented at this level.

An argument by [2] revealed that project commitment at the highest levels of the political system, as well as bureaucracy, and continuous participation from the direct users of the system and other stakeholders in all phases of the project, is necessary for success. Case studies of more successful countries, such as Kosovo, the Slovak Republic, Tanzania and Ethiopia, indicate that the clear commitment by the relevant authorities is one of the main factors supporting successful implementation of an IFMIS [1].

Government policy makers will find the study useful in identifying the shortcomings of the implementation procedures they used [20]. This will guide the ongoing re-engineering processes to be more effective and efficient. In addition, government policy makers may use the research findings in the formulation and enforcement of effective implementation regulations and procedures. With the implementation of IFMIS in the counties, the findings will be used to guide any future re-engineering activities. The research will guide future implementation of Information Technology (IT) applications in Kenya.

The introduction of an IFMIS involves more than only the automation of public finance tasks and processes. An IFMIS must be supported by a coherent legal framework governing the overall public finance system [1]. Amongst other things there should be clear legal guidance on the roles and responsibilities of all institutions in managing, controlling, and monitoring budget execution; the authorization, commitment and release of funds; the basis of accounting (cash or accrual); reporting requirements; and, asset management, public investment and borrowing [21]. According to [1], the implementation of IFMIS in Tanzania was distinguished by revising and developing an enabling legislation which contributed to the success of the system.

An IFMIS generally implies fundamental changes in operating procedures and should be preceded by a detailed functional analysis of processes, procedures, user profiles and requirements that the system will support [1]. Key high-level government goals will only be achieved if the IFMIS solution supports a wide range of business processes that transcend functional, business, organizational and geographic boundaries. IFMIS design should, therefore, be preceded by detailed functional analysis that underpins current functional processes, procedures, user profiles and requirements that the new system will support [21].

In Ghana the design and development of IFMIS was not sufficient due to problems with the reporting functionality. This was because of a lack of clear specifications on the reporting requirements and approval from government on the design of various reports [2]. Business process re-engineering is a critical aspect of any IFMIS reform and requires a review of all systems, functional processes, methods, rules and regulations, legislation, banking arrangements and related processes [14]. It will be necessary to establish new, standardized procedures throughout the government to formalize job descriptions and to improve arrangements and systems for internal and external control.

Many IFMIS projects have failed because the basic system functionality was not clearly specified from the onset of the intervention. In his study, [1] suggests that an IFMIS must be carefully designed to meet the needs and functional requirements, including the accounting and financial management tasks the system should perform. Consideration must be given to the type of systems that will be implemented, for example, off-the-shelf (OTS) or custom-built systems that fit the requirements of the specific country.

An analysis of the different systems used by developing countries indicates that they make use of both off-the shelf systems as well as custom-built systems. For example, Ghana and Uganda opted for a system designed and developed to fit their specific requirements, whilst Tanzania and Malawi opted for off-the shelf systems. It is important to note that a determining factor in the success of the implementation is not in the type of system, (i.e. off-the-shelf or custom-built) but rather in how complicated the system is. One of the reasons for the success of Tanzania's project is, for example, their decision to purchase a less complex, mid-range commercial package [2].

\section{Research Methodology}

The target population comprised of 135 county government employees who use IFMIS in the five counties purposively selected by the researcher. These are employees who are involved in the day to day implementation of IFMIS in the public financial management functions of procurement, finance and accounting officers. The study County principal Accountants, County Senior Procurement Officers, County Assembly Procurement Officers, County Assembly Accountants, County principal Clerk Assistants The study was carried out in Kiambu, Bungoma, Machakos, Nairobi and Nakuru, based on their proximity to the researcher, financial management records and represent $10 \%$ of the county governments of Kenya. Each of the five counties has two arms of government, that is, the county executive and the county assembly.

Table 1. Population of the Study.

\begin{tabular}{|c|c|c|c|c|}
\hline S/No & Department & $\begin{array}{l}\text { No. of } \\
\text { Counties }\end{array}$ & $\begin{array}{l}\text { No. of } \\
\text { staff } \\
\end{array}$ & Total \\
\hline 1. & County Principal Accountants & 5 & 10 & 50 \\
\hline 2 & $\begin{array}{l}\text { County Senior Procurement } \\
\text { Officers }\end{array}$ & 5 & 10 & 50 \\
\hline 3 & $\begin{array}{l}\text { County Assembly Procurement } \\
\text { Officers }\end{array}$ & 5 & 1 & 15 \\
\hline 4 & County Assembly Accountants & 5 & 3 & 15 \\
\hline 5 & $\begin{array}{l}\text { County Principal Clerk } \\
\text { Assistants }\end{array}$ & 5 & 1 & 5 \\
\hline 6 & TOTAL & 5 & 25 & 135 \\
\hline
\end{tabular}

The study adopted snowball sampling technique to 
calculate the sample size. The study sampled 45 respondents representing $30 \%$ of the target population for the purpose of this study. This is because the greater the sample size, the smaller the sampling error and the more representative the sample becomes [4] a sample of $30 \%$ is representative.

In the data collection process questionnaires were administered to the IFMIS county government employees. Confidentiality was assured so as to enhance participation of respondents and IFMIS experts in filling the questionnaires and also to ensure that data gathered was accurate. The questionnaires were administered using a drop and pick later approach so that the respondents had adequate time to answer the questions at their own convenient time.

Data analysis plan involved a detailed analysis to cover all areas of study in relation to the county government IFMIS personnel are i.e. the effect of the independent variables on the implementation of IFMIS service. Each independent variable i.e. perceived benefits, IFMIS success factors; top management commitments, change management, human capital development and technological infrastructure development, challenges and solutions were analyzed individually to determine its effect on the IFMIS implementation. Data for each theme was appropriately summarized, coded and keyed into the computer data base Microsoft Excel Application Programme to generate descriptive characteristics of the data vis- a-vis frequencies and percentages. Microsoft Excel Application Programme and SPSS package Version 18 was used since the researcher is conversant with the programme and it is user friendly.

\section{Results and Discussion}

\subsection{Drivers of IFMIS Adoption}

The study analyzed data on determinants of IFMIS adoption. The findings were as presented in table 2

Table 2. Change Management Assessment Factors.

\begin{tabular}{|c|c|c|c|c|c|}
\hline Change management & 1 & 2 & 3 & 4 & 5 \\
\hline Adequate communication from management & 0 & 34.17 & 1.67 & 51.67 & 12.5 \\
\hline Goals and objectives of IFMIS communicated & 11.67 & 43.33 & 8.33 & 26.67 & 10 \\
\hline IFMIS implementation gradual and consultative & 25 & 47.5 & 11.67 & 11.67 & 4.17 \\
\hline Management involvement and support of IFMIS & 10 & 45 & 8.33 & 30.83 & 5.83 \\
\hline Regular consultative forums on IFMIS implementation & 31.67 & 68.33 & 0 & 0 & 0 \\
\hline Technological Infrastructure & 1 & 2 & 3 & 4 & 5 \\
\hline Reliable network & 0 & 15.00 & 15.00 & 58.33 & 11.67 \\
\hline Regular service and maintenance & 16.67 & 31.67 & 3.33 & 34.17 & 14.17 \\
\hline Technological infrastructure for IFMIS at sub-counties & 0 & 100.00 & 0 & 0 & 0 \\
\hline Human Capital Development & 1 & 2 & 3 & 4 & 5 \\
\hline Adequate training of staff & 0.83 & 40.83 & 6.67 & 51.67 & 0 \\
\hline Regularly planned skills upgrading courses & 49.17 & 50.83 & 0 & 0 & 0 \\
\hline Internal expertise was developed & 2.50 & 3.33 & 0.83 & 75.83 & 17.50 \\
\hline Enough motivation to retain skilled IFMIS personnel & 30.83 & 50.83 & 3.33 & 10.00 & 5.00 \\
\hline Political class is supportive of IFMIS & 47.50 & 50.83 & 1.67 & 0 & 0 \\
\hline Adequate resources allocated to IFMIS implementation & 33.33 & 42.5 & 3.33 & 12.5 & 8.33 \\
\hline Plans underway to roll out IFMIS to sub counties & 49.17 & 40.83 & 4.17 & 5.83 & 0 \\
\hline County strategic plans outline long term plans to support IFMIS & 53.33 & 25.83 & 0 & 11.67 & 9.17 \\
\hline
\end{tabular}

The study revealed that adequate communication from management as shown by high percentage of over 60 indicating general agreement. The goals and objectives of IFMIS are not well communicated as indicated by only 36.675 of the respondents agreeing with the research items. IFMIS implementation was not gradual and consultative as indicated by around $70 \%$ of the respondents disagreeing with the research items. Management involvement and support of IFMIS is average in the counties as shown by $45 \%$ of acceptance. Lastly, there is regular consultative forums on IFMIS implementation indicated by $100 \%$ agreement with research items.

IFMIS implementation implemented just another government directive, without considering the importance of the change management required contrary to the [19] who found that having the users informed on how IFMIS will affect their current work is important in ensuring the success in the implementation as this will reduce resistance by the users and enhance acceptance of the new system. According to [18] change management techniques such as how the project is planned and implemented and end-user involvement in design and the findings of this study indicate that there are no regular consultative forums held for all stakeholders involved in the IFMIS implementation process. This indicated that since the county governments started using the IFMIS, no effort has been made so far to collect feedback on the benefits and challenges of using the system, or advance the skills of those using the system.

The county governments had reliable network as evidenced by over $70 \%$ acceptance with research items. There were inadequate computers connected to IFMIS as revealed by $100 \%$ disagreement with research items. From the findings, it was not clear if there is regular service and maintenance of the IFMIS infrastructure and systems. To a large extent, there were technological infrastructure for IFMIS at sub-counties.

On human capital development, the study established that there is average training of staff as revealed by acceptance rate of $52 \%$. There was lack of regular and planned skills 
upgrading courses as evidenced by $100 \%$ disagreement with questionnaire items. Generally, the county impalements internal expertise as was evidenced by over $90 \%$ agreement with research items. Lastly, there was inadequate motivation to retain skilled IFMIS personnel as evidenced by less than $20 \%$ agreement with research items.

Human capital development issues have not been dealt with adequately, it was reported that most counties did not provide adequate training on IFMIS to their staff; there are no regularly planned skills upgrading courses for IFMIS; and low motivation to retain IFMIS trained staff in the counties. According to [14], capacity building and training need to be focused out during the needs assessment process. Training programs need to address various audiences, from top management to low level management [31]. It was also clearly reported that counties do not offer enough motivation to their workforce so as to be able to retain skilled personnel in IFMIS. This finding are supported by [17] found that one of the reasons for failure of IFMIS in Malawi was due to the fact that the salary structures and terms of employment in government were not attractive and flexible enough to keep staff at the technical and professional level in the presence of better employment opportunities in the private sector.

Study also sought to establish the level of top management commitment. It was evident that political class is not supportive of IFMIS as evidenced by over $87 \%$ disagreement with research items. Resources allocated to IFMIS implementation was low as evidence by low percentage agreement of only $21 \%$. It was not evident if plans are underway to roll out IFMIS to sub counties revealed by over $90 \%$ disagreement with research items. Lastly, the county's strategic plans does not outline long term plans to support IFMIS as revealed by over $88 \%$ disagreement with research items.

The above findings were similar to findings of [18] who indicated that no matter how technically well designed; an IFMIS will ultimately prove powerless when politicians take decisions with fiscal and budgetary implications irrespective of the quality of the apparent laxity of counties to allocate adequate resources or to include IFMIS in the strategic plans [16]. In his study, [17] also argue that when IFMIS work effectively, it eliminates the discretionary power from the controlling officers to allocate resources and overspend, and makes it easy to detect corruption.

Correlation Analysis

The study related the critical success factors with IFMIS adoption through correlation analysis. The findings in table 3 were obtained.

Correlation analysis presented in table 3 indicated that change management, technological infrastructure, human capital development and top management commitment are all critical success factors in adoption of IFMIS in county governments. This is evidenced by positive relationship established through positive Pearson correlation values; $0.213,0.279,0.336$ and 0.386 and significance values of 0.000 .
Table 3. Correlation Analysis.

\begin{tabular}{lll}
\hline Variable & & IFMI Adoption \\
\hline \multirow{2}{*}{ Change management } & Pearson Correlation & $.213^{* *}$ \\
& Sig. (1-tailed) & .001 \\
Technological Infrastructure & Pearson Correlation & $.279^{* *}$ \\
& Sig. (1-tailed) & .000 \\
Human Capital Development & Pearson Correlation & $.336^{* *}$ \\
& Sig. (1-tailed) & .000 \\
Top management commitment & Pearson Correlation & $.386^{* *}$ \\
& Sig. (1-tailed) & .000 \\
\hline
\end{tabular}

\subsection{Conclusions and Recommendations}

Based on the study findings summarized above, the study concludes that: Most of the counties have implemented the IFMIS in their financial procedures; those experiencing financial wastage have not undertaken proper change management when integrated financial management information systems (IFMIS) were introduced. The main perceived benefits of IFMIS by the county employees were: enhanced transparency and accountability, elimination of overspending, budget management, automated reconciliation of banking data and fully reconciled fiscal data In terms of technical performance of the IFMIS service and performance in terms enhancing transparency, accountability and convenience positively influenced the implementation of IFMIS, thus IFMIS met the expectations of the county IFMIS personnel. The cost saving aspect was found to positively influence the county government to implement to IFMIS, The IFMIS services were compatible with the counties ' current financial management and budgeting needs, because it positively influenced their saving capability and how to manage county resources. Also the fact that the IFMIS service was tailor made to meet the specific needs of counties positively influenced the county to implementation to IFMIS service. The counties felt that IFMIS system was secure but it is run on poor network architecture affecting its uptime and causing financial inconveniences.

It was also concluded that change management, technological infrastructure, human capital development and top management commitment are all critical success factors in adoption of IFMIS in county governments. The government must therefore have in place systems that ensure the above factors are in place if adoption of IFMIS is to be successful in the counties.

On the basis of this study, the following recommendations are made; that for the counties to have a satisfactory impact of IFMIS functions, they should seek internal acceptance of IFMIS by all stakeholders by educating them more on the benefits; consulting them more; and management should lead by example by being more proactive and supportive. Skills advancement courses should be planned on a more regular basis for staff working with IFMIS and motivation provided to retain the trained staff in the counties [9]. The technological infrastructure required to roll out IFMIS to the sub counties should be provided to decentralize operations from the county headquarters. The political class should also change their attitudes towards IFMIS and provide more supportive leadership and the counties should include long term plans 
towards the support of IFMIS in their strategic plans since the benefits realized with implementation of IFMIS far outweigh challenges. Further investigations should be carried out on impact of IFMIS on the public financial management of the counties and influence of political will on the effective implementation and sustainability of IFMIS in the county governments of Kenya

\section{References}

[1] Chene, M. (2009). The Implementation of Integrated Financial Information Systems.www.docstoc.com, accessed on 11th July, 2015 Developing Countries. IMF Working Paper, Fiscal Affairs Department, WP/05/196.

[2] Diamond, J. and Khemani, P. (2005). Introducing Financial Management Information Systems in International Publishers.

[3] Kimwele, J. (2011). Factors Affecting Effective Implementation of Integrated Financial Management Information Systems in Government Ministries in Kenya. Unpublished Dissertation, University of Nairobi.

[4] Kothari, C. (2004). Research methodology, methods and techniques. India, New Delhi; New Age.

[5] Lianzuala, A. and Khawlhring, E. (2008). IFMIS Project. www.docstoc.com, accessed on 12th, July 2015.

[6] Liu, S. and Hwang, J. (2003). Challenges to transforming IT in the US government. IT Professional 5 (3), 10-15.

[7] Muigai, M. (2012). The effect of Integrated Financial Management Information Systems on the financial management of the public sector in Kenya: A case of the Kenyan ministries. Unpublished Dissertation, University of Nairobi.

[8] Mutui, M. (2014). Integrated Financial Management Information Systems and Procurement performance of the public sector in Kenya. Unpublished Dissertation, University of Nairobi.

[9] Mzyece, M. (2006). A Critical Analysis of E-government in Zambia. The African Journal of Information and Communication, Issue No.12, 2012.

[10] Nah, F., Zuckweiler, K. \& Lau, J. (2003). ERP implementation: Chief information officers' perceptions of critical success factors. International Journal of Human-Computer Interaction, 16(1), 5-22. Retrieved June 3, 2013 from EBSCO Host. Business Source Complete, AN 10302015.

[11] Njonde, J. and Kimanzi, K. (2014). Effect of Integrated Financial Management Information Systems on Performance of the public sector. A case of Nairobi County Government. International Journal of Social Sciences and Entrepreneurship 1 (12), 913-936.

[12] Njoroge, O. (2014). IFMIS will end corruption in the counties. www.shitemi.com, accessed on 2nd June, 2015.

[13] Office of the Controller of Budget (2014). County budget implementation review report, First quarter 2014/2015. www.cob.go.ke, accessed on 20th March, 2015.
[14] Rodin-Brown, E. (2008). Integrated Financial Management Information Systems: A Practical Guide. Fiscal Reform and Economic Governance Task Order, GEG-1-00-04-00001-00 Task Order No.8; USAID.

[15] Strejcek, G. and Theil, M.(2002). Technology Push, Legislation Pull. E-government in the European Union. Decision Support Systems 34 (3), 305-313.

[16] ICPAK, (2014). A Baseline Survey on Devolution in Kenya with Respect to Public Financial Management Systems - One year on, ICPAK ISBN No. 978-9966-1808-0-3.

[17] Durevall, D. and Erllandsson, M. (2005). Public Financial Management Reform in Malawi, SIDA Country Economic Report 2005: 1. Sweden; Gotenburg University,

[18] Dorotinsky, W. and Matsuda, Y. (2001). Financial Management Reform in Latin America: An Institutional Perspective. Washington D. C; The World Bank Group.

[19] Miheso, S. (2013). Adoption of Integrated Financial Management Information Systems by National Government in Kenya. Unpublished Dissertation, University of Nairobi.

[20] Nyagah, E. (2006). An investigation of critical success factors for successful Implementation of enterprise resource planning (ERP) Systems in Kenya.

[21] Pinto J. \& Slevin D. (1987). Critical Success Factors in Effective Project implementation, pp. 20-27.

[22] Umble E., Haft R. and Umble M. (2003). Enterprise resource planning: implementation procedures and critical success factors. European Journal of Operational research, 146, 241-257.

[23] Hendriks, C. J., (2012). Integrated Financial Management Information Systems: Guidelines for effective implementation by the public sector of South Africa. SA Journal of Information Management 14 (1), Art. Retrieved from http://dx.doi.org/10.4102/ sajim.v14i1.529.

[24] Doom, C., Milis, K., Poelmans, S. \& Bloemen, E. (2009). Critical success factors for ERP implementations in Belgian SMEs. Journal of Enterprise Information Management, 4623 (3), 378-406.

[25] Hove, M. \& Wynne, A., (2010). The experience of medium term expenditure framework \& integrated financial management information system reforms in sub-Saharan Africa: What is the balance sheet? Retrieved July 7, 2013 from http://www.acbf-pact.org/knowledge/documents/Occasional_ Paper 9.pdf.

[26] Brar, P., (2010). IFMIS in Africa: Some key issues. Retrieved 11 June 2013 from http:// www.eastafritac.org/images/uploads/documents_storage/IFMI S_Workshop_Day_1_Presentations.pdf.

[27] Grabski, S. \& Leech, S. (2007). Complementary controls and ERP implementation success. International Journal of Accounting Information Systems, 8, 17-39. Retrieved April 5, 2013 from EBSCO Host Business Source Complete, AN 24301862 .

[28] Fawaz, K., Al-Salti, Z. \& Eldabi, T. (2008). Critical success factors in ERP implementation: A review. European and Mediterranean Conference on Information Systems. Retrieved May 12, 2013 from EBSCO Host. Business Source Complete, AN 1403525. 
[29] Randeree, K. \& Ninan, M. (2009). Leadership and teams in business: A study of IT projects in the United Arab Emirates. International Journal of Managing Projects in Business, 4 (1), $28-48$.

[30] Rockart, J. F. (1999). Chief executives define their own data needs. Harvard Business Review, pp 81-93. Retrieved June 9, 2013 from http://hbr.org/1979/03/chief-executives-define-their-own-data needs/.

[31] Payne, V. (2010). ERM framework. Enterprise Risk Journal, 9 (5), 1-15. 